九州大学学術情報リポジトリ

Kyushu University Institutional Repository

\title{
Effects of Tributyltin and Diazinon on the Intertidal Marine Harpacticoid Copepod Tigriopus japonicus
}

TAKAI, Yuki

Laboratory of Marine Environmental Science, Division of Animal and Marine Bioresource Sciences, Department of Bioresource Sciences, Graduate school of Bioresource and Bioenvironmental Sciences, Kyushu University

TANOUE, Wataru

Laboratory of Marine Environmental Science, Department of Bioresource Sciences, Faculty of Agriculture, Kyushu University

QIU, Xuchun

Institute of Environmental Health and Ecological Security, School of Environment and Safety Engineering, Jiangsu University

TAKAKU, Hiroshi

Head Office, Marine Ecology Research Institute

他

https://doi.org/10.5109/4103893

出版情報: 九州大学大学院農学研究院紀要. 65 (2)，pp.289-294，2020-09. Faculty of Agriculture， Kyushu University

バージョン :

権利関係 : 


\title{
Effects of Tributyltin and Diazinon on the Intertidal Marine Harpacticoid Copepod Tigriopus japonicus
}

\author{
Yuki TAKAI ${ }^{1}$, Wataru TANOUE ${ }^{2}$, Xuchun QIU $^{3}$, Hiroshi TAKAKU ${ }^{4}$, Ik Joon KANG ${ }^{5}$, \\ Yohei SHIMASAKI ${ }^{2}$, Tsuneo HONJO ${ }^{2}$ and Yuji OSHIMA ${ }^{2,6 *}$
}

\author{
Laboratory of Marine Environmental Science, Department of Bioresource Sciences, \\ Faculty of Agriculture, Kyushu University, 744, Motoka, Nishi-ku, Fukuoka 819-0395, Japan
} (Received May 7, 2020 and accepted May 27, 2020)

\begin{abstract}
The intertidal zone plays an important role in the ecology of coastal waters by providing marine organisms a place to feed, grow, and spawn. Because the organisms that inhabit these areas may be contaminated and adversely affected by pollutants, an assessment of the impact of pollutants on intertidal zone organisms is needed. Tributyltin and diazinon are environmental pollutants that have been detected in coastal waters and are well known to be highly toxic to aquatic organisms. In this study, we performed acute and life-cycle toxicity tests with an intertidal organism, the copepod Tigriopus japonicus. The $48 \mathrm{~h}-\mathrm{LC50}$ (i.e., the concentration that killed half the organisms in $48 \mathrm{~h}$ ) values for tributyltin revealed that nauplii ( $48 \mathrm{~h}-\mathrm{LC} 50$; $3.72 \mu \mathrm{g} / \mathrm{L}$ ) were more sensitive to tributyltin than adult males and gravid females (48 h-LC50; 7.16 and $7.69 \mu \mathrm{g} / \mathrm{L}$, respectively). In contrast, the $48 \mathrm{~h}-\mathrm{LC50} 0$ values for diazinon showed that adult male and gravid females (48 h-LC50; 164 and $216 \mu \mathrm{g} / \mathrm{L}$, respectively) were more sensitive to diazinon than nauplii (48 hLC50; $>1400 \mu \mathrm{g} / \mathrm{L})$. Life-cycle toxicity tests with tributyltin or diazinon showed that tributyltin and diazinon reduced the fecundity of T. japonicus under the experimental conditions. The lowest concentrations of tributyltin and diazinon that reduced the fecundity of T. japonicus were found to be $1.6 \mu \mathrm{g} / \mathrm{L}$ and $15.7 \mu \mathrm{g} / \mathrm{L}$, respectively. Although the risk of exposure to tributyltin and diazinon individually in the environment was estimated to be negligible, a mixture of the two might exert adverse effects on $T$. japonicus in the intertidal zone.
\end{abstract}

Key words: diazinon, intertidal zone, life-cycle toxicity test, Tigriopus japonicus, tributyltin

\section{INTRODUCTION}

A variety of pollutants that are toxic to marine organisms have become a concern because of their impact on marine ecosystems (Beiras, 2018). Xenobiotics such as antifouling paints and pesticides have contaminated some aquatic ecosystems. Pollutants that are discharged directly into coastal waters or delivered via streams eventually reach the intertidal zone. A wide range of chemical pollutants, including polycyclic aromatic hydrocarbons (PAHs) (Tipmanee et al., 2012), persistent organic pollutants (POPs) (Fu et al., 2003), and heavy metals (Zhou et al., 2007), can be introduced into coastal waters. In previous studies, a variety of pollutants (e.g., tributyltin, radioisotopes, and PAHs) have

\footnotetext{
Laboratory of Marine Environmental Science, Division of Animal and Marine Bioresource Sciences, Department of Bioresource Sciences, Graduate school of Bioresource and Bioenvironmental Sciences, Kyushu University, Fukuoka 8190395, Japan

2 Laboratory of Marine Environmental Science, Department of Bioresource Sciences, Faculty of Agriculture, Kyushu University, Fukuoka 819-0395, Japan

Institute of Environmental Health and Ecological Security, School of the Environment and Safety Engineering, Jiangsu University, Zhenjiang, Jiangsu 212013, P.R. China

${ }^{4}$ Head Office, Marine Ecology Research Institute, Tokyo 1620801 Japan

School of Interdisciplinary Science and Innovation, Kyushu University

${ }^{6}$ Institute of Nature and Environmental Technology, Kanazawa University, Kanazawa 920-1192, Japan

* Corresponding author (E-mail: yoshima@agr.kyushu-u.ac.jp)
}

been detected in wharf roaches (Ligia sp.) collected from the coastal zone (Honda et al., 2018; Qiu et al., 2017; Undap et al., 2013a). In addition, heavy oil spilled from tankers such as the Torrey Canyon, Nakhodka, and Prestige has caused severe impacts on coastal environments (Chen et al., 2019). In coastal waters, the intertidal zone plays an important role by providing places for marine organisms to feed, grow, and spawn (Gibson, 2001). Organisms that inhabit coastal waters are therefore likely to be contaminated by and adversely affected by pollutants.

Tributyltin (TBT) is a highly toxic chemical that has been used worldwide in antifouling paints, mainly on ships and aquaculture facilities, to prevent the growth of marine organisms such as bacteria, mussels, and algae (Batley and Scammell, 1991; Cardwell et al., 1999; Ko et al., 1995; Murai et al., 2005). It is well known that TBT severely disrupts the endocrine systems of marine organisms, and impaired sexual development is among the typical and severe impacts of TBT on marine organisms (Horiguchi et al., 1997; Matthiessen and Gibbs, 1998; Shimasaki et al., 2003). Although use of TBT is strictly regulated because of its potent toxicity to nontarget organisms, a number of countries have not yet ratified the control of TBT for shipping activities (IMO, 2020), and TBT is still detected in coastal areas (Sheikh et al., 2020; Undap et al., 2013b). Because TBT is adsorbed on floating objects such as plastic debris (Carter et al., 1989) and on aquatic microorganisms (Gadd, 2000), it is likely to reach and be widely distributed in the intertidal zone, where it may affect intertidal 
organisms.

Diazinon (O,O-diethyl-O-[2-isopropyl-6-methyl-4pyrimidinyl] phosphoro thioate) is an organophosphate insecticide that is used in agricultural fields worldwide (Bailey et al., 2000). Its irreversible inhibition of cholinesterase is known to be primarily responsible for the toxicity of diazinon, and it is also well established that diazinon is highly toxic to vertebrate animals as well as insects (Davies and Holub, 1980; Keizer et al., 1995; Nakagawa and Moore, 1999). Diazinon has been detected mainly in agricultural fields (GóngoraEcheverría et al., 2019; Ngolo et al., 2019), but it has also been detected in rivers and coastal areas (Derbalah et al., 2019; Köck-Schulmeyer et al., 2019). It has therefore been suggested that diazinon may be affecting organisms in the intertidal zone.

Harpacticoid copepods such as Tigriopus sp. have been widely used as model organisms in eco-toxicity tests (Barka et al., 2001; O'Brien et al., 1988). Tigriopus japonicus is a marine harpacticoid copepod that lives in the intertidal zone around East Asia; it has been widely used as a marine model organism in many scientific studies (Marcial et al., 2003; Rhee et al., 2009). Tigriopus japonicus is easily maintained under artificial conditions. The well-known ontogeny and life cycle of $T$. japonicus include six naupliar stages and five copepodid stages before T. japonicus reaches adulthood and sexual maturity. Furthermore, T. japonicus males can be easily distinguished from females based on their first antenna and fifth swimming legs. These characteristics make T. japonicus a model organism well suited for observation of the effects caused by chronic exposure to chemical substances (Raisuddin et al., 2007). In the intertidal zone, risk analysis studies with T. japonicus have been performed mainly with pollutants such as TBT (Kwok and Leung, 2005) and oil (Lee et al., 2013). However, few risk analysis studies of pesticide toxicity to T. japonicus have been performed. To evaluate the environmental risks of TBT and diazinon in the intertidal zone, we performed acute toxicity tests and life-cycle toxicity tests with T. japonicus exposed to TBT and diazinon.

\section{MATERIALS AND METHODS}

\section{Harpacticoid copepod}

The harpacticoid copepod T. japonicus was obtained from the Marine Ecology Research Institute (Chiba, Japan), and maintained in culture in our laboratory. T. japonicus was cultured in $2-\mathrm{L}$ glass beakers with artificial seawater (salinity of 30, dissolved oxygen $>6 \mathrm{mg} / \mathrm{L}, 25 \pm 1^{\circ} \mathrm{C}$ ) (Marine Art SF-1, Tomita Pharmaceutical, Tokushima, Japan). T. japonicus was maintained on a $12 \mathrm{~h}: 12 \mathrm{~h}$ (light:dark) cycle of illumination and fed the green alga Tetraselmis tetrathele, which was cultured in modified SWM-3 medium (Itoh and Imai, 1987).

\section{Chemical substances}

Tributyltin (Tri- $n$-butyltin oxide, $>95 \%$ pure) was purchased from the Tokyo Chemical Industry (Tokyo, Japan). The TBT was dissolved in ethanol to prepare a stock solution of $300 \mu \mathrm{g} / \mathrm{mL}$. The stock solution was stored in the dark at $4^{\circ} \mathrm{C}$. The ethanol concentrations in the test solution was $<0.1 \mathrm{~mL} / \mathrm{L}$.

Diazinon (diethyl 2-isopropyl-4-methyl-6-pyrimidinyl phosphonothioate, $99 \%$ pure), was purchased from Wako Pure Chemical (Tokyo, Japan). The diazinon was dissolved in dimethylformamide (DMF) to prepare a stock solution of $14 \mathrm{mg} / \mathrm{mL}$. The stock solution was stored in the dark at $4^{\circ} \mathrm{C}$. Test solutions were prepared by pipetting calculated amounts of the stock solutions into known volumes of the artificial seawater. The DMF concentrations in the test solution were $<0.1 \mathrm{~mL} / \mathrm{L}$.

\section{Determination of TBT and diazinon concentra- tions in test solutions}

TBT and diazinon concentrations in the test solutions were verified analytically with a gas chromatograph equipped with a mass spectrometer (GC/MS) at the beginning of the exposure tests. Analyses of TBT concentrations in the test solutions were performed as previously described (Inoue et al., 2006). The TBT concentrations were analyzed using a GC/MS (model 6890 gas chromatograph, model 5973 mass spectrometer, Hewlett-Packard, California, USA). The dissolved diazinon was extracted from 1-L samples in a solidphase extraction cartridge (Sep-Pak, Waters Corporation, Massachusetts, USA) and then eluted with $5 \mathrm{~mL}$ of dichloromethane. The eluate was concentrated to $1 \mathrm{~mL}$ and analyzed using GC/MS. The concentrations of TBT and diazinon reported here are the concentrations that we measured in this way.

\section{8-h acute toxicity tests}

Acute toxicity tests were performed to estimate the concentrations that killed $50 \%$ of the test organisms in 48 h (48 h-LC50) using nauplii ( $<24$ hours old), adult male, and gravid female (9 days old) copepods. Exposure concentrations of TBT were 1.78, 5.65, 7.82, $12.4,24.4 \mu \mathrm{g} / \mathrm{L}$, and a solvent control (ethanol, 0.01\% [v/v]) for nauplii and adult copepods. Exposure concentrations of diazinon were $1.4,14,140,1400 \mu \mathrm{g} / \mathrm{L}$, and a solvent control (DMF, 0.01\% [v/v]) for nauplii; and 19.5, 35.6, 73.1, 142, 326 $\mu \mathrm{g} / \mathrm{L}$, and a solvent control (DMF, $0.01 \%[\mathrm{v} / \mathrm{v}])$ for the adult copepods. These exposure concentrations were selected based on preliminary exposure tests. Eight nauplii were transferred by Pasteur pipette to 5-mL glass Petri dishes containing $5 \mathrm{~mL}$ of test solution at each concentration, and 8 adult male or gravid female copepods were transferred by glass pipette to $100-\mathrm{mL}$ glass beakers containing $100 \mathrm{~mL}$ of test solution at each concentration. After exposures of $24 \mathrm{~h}$ and $48 \mathrm{~h}$, the mortalities of the copepods were assessed. Copepods were not fed during the exposure period. The experimental cultivation conditions were otherwise the same as the normal cultivation conditions.

\section{Life-cycle toxicity tests}

Life-cycle toxicity tests were performed as 
described in previous studies (Hutchinson et al., 1999; Marcial et al., 2003 ) but with a slight modification. In the life-cycle toxicity test for TBT, experimental treatments consisted of a control, solvent control (ethanol, $0.01 \%[\mathrm{v} / \mathrm{v}])$, and four concentrations of TBT $(0.45,0.88$, 1.6 , and $3.9 \mu \mathrm{g} / \mathrm{L})$. In the life-cycle toxicity test for diazinon, the treatments consisted of a control, solvent control (DMF, 0.01\% [v/v]), and five concentrations of diazinon $(7.73,15.7,33.1,73.6$, and $147 \mu \mathrm{g} / \mathrm{L})$. These concentrations were selected based on $48-\mathrm{h}$ acute toxicity tests.

Five nauplii $(<24$ hours after hatching) were transferred into a 5-mL glass Petri dish filled with $4 \mathrm{~mL}$ of test solution. There were four replicates in each group. The exposure period was set to 16 days. The test solution contained T. tetrathele $\left(1 \times 10^{5} \mathrm{cells} / \mathrm{mL}\right)$ and was renewed every two days during the exposure period. Survival and the developmental stage of the copepods were observed every $24 \mathrm{~h}$ using a stereo microscope (SMZ, Nikon, Tokyo, Japan). After a 6-d exposure, all surviving copepods from each test concentration were transferred to $100-\mathrm{mL}$ glass beakers containing $20 \mathrm{~mL}$ of test solution with $T$. tetrathele to initiate copulation. After 2 or 3 days, all gravid females, each bearing an ovisac, were individually transferred into 5-mL glass Petri dishes. After the gravid females had spawned, the number of nauplii was counted for each copepod. The cultivation conditions during this test were the same as normal cultivation conditions (salinity of 30, dissolved oxygen $>6 \mathrm{mg} / \mathrm{L}, 25 \pm 1^{\circ} \mathrm{C}, 12 \mathrm{~h}: 12 \mathrm{~h}$ light:dark cycle of illumination).

\section{Statistical analysis}

48 h-LC50 values for each chemical were determined with a logistic regression model (Piegorsch and Bailer, 2005). Calculations were performed with $\mathrm{R}$ software (version 3.6.2, https://cran.r-project.org/). The $48 \mathrm{~h}-\mathrm{LC50}$ estimates were based on the measured concentrations of each chemical. The differences of the survival rates between the control and exposure groups were analyzed with a log-rank test in R. The differences in fecundity and the number of days required to attain the copepodid stage and to become gravid were analyzed by Dunnett's test in R. Differences in sex ratios were analyzed by two-sample tests for equality of proportions in $\mathrm{R}$. A type I error rate ( $p$-value) less than 0.05 was regarded as being significant for all tests.

\section{RESULTS}

\section{$48 \mathrm{~h}-\mathrm{LC50}$}

The 48 h-LC50 values for TBT were higher in adult males and gravid females (7.16 and $7.69 \mu \mathrm{g} / \mathrm{L})$ than in nauplii $(3.72 \mu \mathrm{g} / \mathrm{L})$ (Table 1$)$. The $48 \mathrm{~h}-\mathrm{LC} 50$ values for diazinon were higher in nauplii $(>1400 \mu \mathrm{g} / \mathrm{L})$ than in adult males and gravid females (164 and $216 \mu \mathrm{g} / \mathrm{L}$, respectively) (Table 1 ).

\section{Survival rate in life-cycle toxicity tests}

In the TBT treatment group, the survival rate of $T$.
Table 1. Acute toxicities (48h-LC50s) of TBT and diazinon to $T$. japonicus

\begin{tabular}{cccc}
\hline \multicolumn{4}{c}{$48 \mathrm{~h}-\mathrm{LC} 50(\mu \mathrm{g} / \mathrm{L})$} \\
\hline & Nauplius & Adult male & Gravid female \\
\hline TBT & 3.72 & 7.16 & 7.69 \\
Diazinon & $>1400$ & 164 & 216 \\
\hline
\end{tabular}
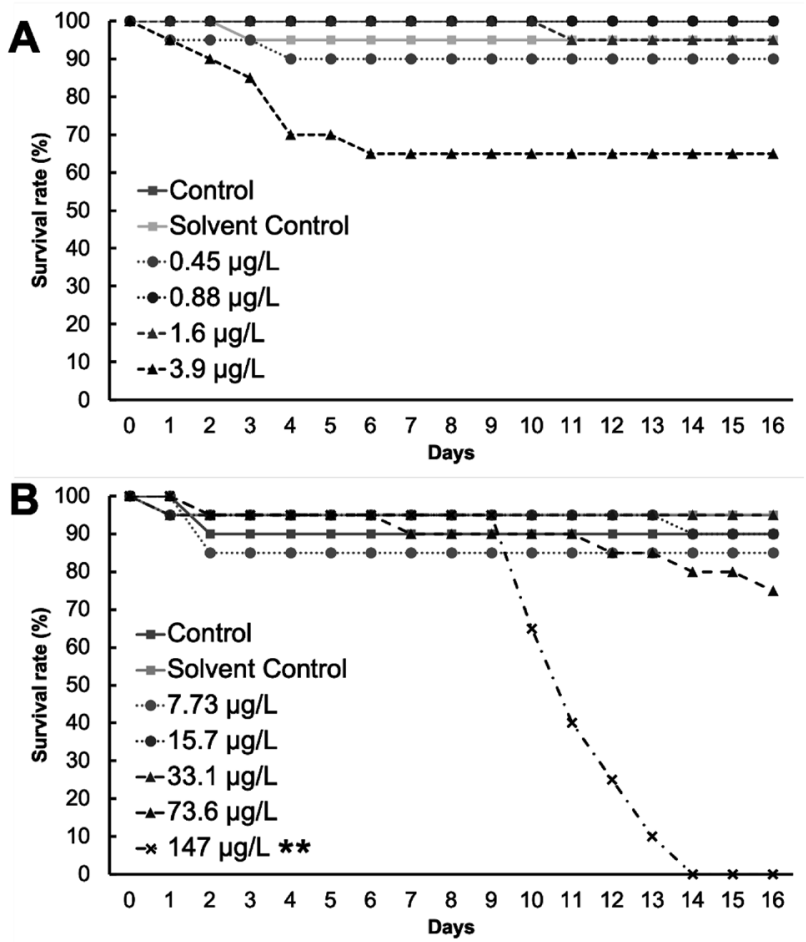

Fig. 1. The survival rate of Tigriopus japonicus in the life-cycle exposure test.

A. The survival rate in the TBT exposure group. B. The survival rate in the diazinon exposure group. Significant differences versus the control group are indicated by asterisks $(* *)$ that indicate $p<0.01$ (log-rank test).

japonicus was unaffected by TBT concentrations $\leq 1.6 \mu \mathrm{g} / \mathrm{L}$. In the group exposed to $3.9 \mu \mathrm{g} / \mathrm{L}$ TBT, the survival rate at 6 days decreased from $90-100 \%$ to $65 \%$ (Fig. 1A). The survival rates of copepods in the diazinon treatment group were unaffected by concentration $\leq 73.6 \mu \mathrm{g} / \mathrm{L}$. At 14 days, however, the mortality of copepods exposed to $147 \mu \mathrm{g} / \mathrm{L}$ diazinon was $100 \%$ ( $p<0.01$, Fig. 1B).

\section{The effects of TBT on the life-cycle of $T$. japoni- cus}

The elapsed time from hatching to the copepodid stage was delayed from 4 days to 4.4 days in the group exposed to $3.9 \mu \mathrm{g} / \mathrm{L}$ TBT $(p<0.05$, Table 2$)$. The elapsed time from hatching to maturation was significantly delayed from 10 days to 11 days or 15 days in the groups exposed to $1.6 \mu \mathrm{g} / \mathrm{L}$ or $3.9 \mu \mathrm{g} / \mathrm{L}$ TBT, respectively $(p<0.05$, Table 2). No significant differences were found in the sex ratios of the control group and exposure 
Table 2. The elapsed time for development and fecundity of T. japonicas

\begin{tabular}{|c|c|c|c|c|}
\hline $\mathrm{TBT}$ & $\begin{array}{l}\text { Nauplius stage }^{a} \\
\text { (days) }\end{array}$ & $\begin{array}{l}\text { Maturation stage } \\
\text { (days) }\end{array}$ & $\begin{array}{c}\text { Sex ratio } \\
\text { (female/male) }\end{array}$ & $\begin{array}{c}\text { Fecundity }^{\mathrm{d}} \\
\text { (nauplii/female) }\end{array}$ \\
\hline Control & $4.1 \pm 0.2$ & $10.0 \pm 0.6$ & 6/14 (0.4) & $76.8 \pm 21.3$ \\
\hline Solvent control & $3.7 \pm 0.5$ & $9.3 \pm 0.5$ & $4 / 15(0.3)$ & $84.5 \pm 14.9$ \\
\hline $0.45 \mu \mathrm{g} / \mathrm{L}$ & $4.0 \pm 0.0$ & $10.3 \pm 0.7$ & $12 / 6(2.0)$ & $55.5 \pm 29.9$ \\
\hline $0.88 \mu \mathrm{g} / \mathrm{L}$ & $4.0 \pm 0.0$ & $10.7 \pm 0.7$ & $10 / 10(1.0)$ & $53.3 \pm 36.9$ \\
\hline $1.6 \mu \mathrm{g} / \mathrm{L}$ & $4.0 \pm 0.0$ & $11.0 \pm 0.7^{*}$ & $9 / 10(0.9)$ & $45.9 \pm 32.2$ \\
\hline $3.9 \mu \mathrm{g} / \mathrm{L}$ & $4.4 \pm 0.7^{*}$ & $15.0 \pm 1.4^{*}$ & $2 / 11(0.2)$ & $2.0 \pm 2.8^{*}$ \\
\hline Diazinon & $\begin{array}{l}\text { Nauplius stage }^{\mathrm{a}} \\
\text { (days) }\end{array}$ & $\begin{array}{c}\text { Maturation satage } \\
\text { (days) }\end{array}$ & $\begin{array}{c}\text { Sex ratio }^{c} \\
\text { (female/male) }\end{array}$ & $\begin{array}{c}\text { Fecundity }^{d} \\
\text { (nauplii/female) }\end{array}$ \\
\hline Control & $3.8 \pm 0.4$ & $9.2 \pm 0.4$ & $6 / 12(0.5)$ & $72.8 \pm 14.3$ \\
\hline Solvent control & $3.9 \pm 0.5$ & $9.1 \pm 0.6$ & $8 / 11(0.7)$ & $79.8 \pm 14.1$ \\
\hline $7.73 \mu \mathrm{g} / \mathrm{L}$ & $3.6 \pm 0.6$ & $9.6 \pm 2.0$ & 8/9 (0.9) & $63.9 \pm 36.8$ \\
\hline $15.7 \mu \mathrm{g} / \mathrm{L}$ & $3.8 \pm 0.6$ & $9.8 \pm 0.8$ & $5 / 14(0.4)$ & $34.8 \pm 23.1^{*}$ \\
\hline $33.1 \mu \mathrm{g} / \mathrm{L}$ & $4.1 \pm 0.2$ & $9.3 \pm 0.9$ & $9 / 10(0.9)$ & $1.0 \pm 3.0^{*}$ \\
\hline $73.6 \mu \mathrm{g} / \mathrm{L}$ & $3.8 \pm 0.8$ & $9.5 \pm 0.7$ & 6/9 (0.7) & $0^{*}$ \\
\hline $147 \mu \mathrm{g} / \mathrm{L}$ & $4.0 \pm 0.0$ & - & - & $0^{*}$ \\
\hline
\end{tabular}

Significant changes versus control group $(p<0.05)$ are indicated by an asterisk $(*)$. (a) The time from hatching to reaching the copepodid stage. (b) The time from female birth to bearing an ovisac. (c) The sex ratio of adult copepods. (d) The number of nauplii produced by one female copepod.

groups (Table 2). Copepod fecundity was dramatically decreased in the group exposed to $3.9 \mu \mathrm{g} / \mathrm{L}$ TBT $(p<$ 0.05 , Table 2). In the control group, 76 nauplii were produced per female, but only 2 nauplii were produced per copepod in the group exposed to $3.9 \mu \mathrm{g} / \mathrm{L}$ TBT. Based on the results of copepod TBT-exposure tests, the no observed effect concentration (NOEC) was estimated to be $0.88 \mu \mathrm{g} / \mathrm{L}$, and the lowest observed effect concentration (LOEC) was estimated to be $1.6 \mu \mathrm{g} / \mathrm{L}$. The predicted no-effect concentration (PNEC) of TBT was calculated from the NOEC with an assessment factor (AF) of 100 and was estimated to be $8.8 \mathrm{ng} / \mathrm{L}$ (3.6 ng Sn/L) (ECC, 2003)

\section{The effects of diazinon on the life-cycle of $T$. japonicus}

In the diazinon treatment group, all copepods in the group exposed to $147 \mu \mathrm{g} / \mathrm{L}$ diazinon were dead before they bore ovisacs (Fig. 1B). There was no significant effect of diazinon exposure on the elapsed time for copepod development or on the sex ratio (Table 2). However, there was a significant decrease of fecundity in the groups exposed to $15.7,33.1,73.6$, and $147 \mu \mathrm{g} / \mathrm{L}$ diazinon $(p<0.05$, Table 2$)$. In the control group, approximately 72 nauplii were produced per female . However, only 0-1 nauplii per female were produced in the groups exposed to diazinon at concentrations of $33.1-147 \mu \mathrm{g} / \mathrm{L}$ (Table 2). In the group exposed to $73.6 \mu \mathrm{g} / \mathrm{L}$ diazinon, no gravid females produced nauplii, even though females bore ovisacs. Based on the results of diazinon exposure to copepods, the NOEC and LOEC were estimated to be $7.73 \mu \mathrm{g} / \mathrm{L}$ and $15.7 \mu \mathrm{g} / \mathrm{L}$, respectively. The PNEC of diazinon was calculated from the NOEC with an AF of 100 and was estimated to be
$77.3 \mathrm{ng} / \mathrm{L}(\mathrm{ECC}, 2003)$

\section{DISCUSSION}

The 48-h acute toxicity tests revealed that nauplii were more sensitive to TBT than adult copepods, i.e., the $48 \mathrm{~h}-\mathrm{LC5} 0$ was lower for nauplii $(3.72 \mu \mathrm{g} / \mathrm{L})$ than for adult male and gravid female copepods (7.16 and $7.69 \mu \mathrm{g} / \mathrm{L}$, respectively). This result was consistent with the results of previous studies on other harpacticoid copepods; those studies have demonstrated that nauplii are more sensitive to toxic chemicals than copepodids or adult copepods (Guo et al., 2012; Verriopoulos and Moraïtou-Apostolopoulou, 1982).

In the life-cycle toxicity tests with TBT, all copepods exposed to $3.9 \mu \mathrm{g} / \mathrm{L}$ TBT developed from hatching to copepodids in about 5 days. The survival rate decreased during 6 days of exposure to $3.9 \mu \mathrm{g} / \mathrm{L}$ TBT (Fig. 1A) but was then stable until the end of the exposure test. This result was in accord with the results of previous studies of the acute toxicity of TBT, which have demonstrated that the tolerance of $T$. japonicus to TBT increases through ontogenetic development from nauplius to copepodid (Guo et al., 2012; Verriopoulos and MoraïtouApostolopoulou, 1982).

In contrast, the results of the diazinon 48-h acute toxicity tests demonstrated that adult copepods were more sensitive to diazinon than nauplii, i.e., the $48 \mathrm{~h}-$ LC50 was higher for nauplii ( $>1400 \mu \mathrm{g} / \mathrm{L})$ than for adult male and gravid female copepods (164 and $216 \mu \mathrm{g} / \mathrm{L}$, respectively). This result agreed well with the results of the previous study of Rompas et al. (1989), which demonstrated that tiger shrimp post-larvae are more sensitive to an organophosphate pesticide (fenitrothion) than 
nauplii. Kobayashi et al. (1990) have also indicated that the metabolic activity of tiger shrimp larvae exposed to the thiono-form and oxo-form of the organophosphate in fenitrothion increases as the larvae grow. They have demonstrated that the oxo-form is more toxic to the larvae than the thiono-form. In this study, the survival rate of T. japonicus exposed to $147 \mu \mathrm{g} / \mathrm{L}$ diazinon began to decrease significantly after maturation to the adult copepod stage. These results suggested that tolerance to diazinon decreased during ontogenetic development from nauplius to adult copepod. We therefore hypothesized that the metabolism of diazinon by T. japonicus increased during its growth and that an increase of the oxo-form of diazinon caused its high toxicity to adult $T$. japonicus.

The life-cycle toxicity tests revealed that copepods exposed to $73.6 \mu \mathrm{g} / \mathrm{L}$ diazinon or $3.9 \mu \mathrm{g} / \mathrm{L}$ TBT could not produce nauplii, even though gravid females bore ovisacs. These results indicated that diazinon and TBT inhibit and/or delay the production of nauplii. In contrast, Lee et al. (2008) have shown that exposure to $10 \mu \mathrm{g} / \mathrm{L}$ TBT does not affect the fecundity of T. japonicus. In this study, we used a glass Petri dish and beaker as a test chamber and estimated the $48 \mathrm{~h}-\mathrm{LC50}$ of TBT for adult copepods to be $7.16 \mu \mathrm{g} / \mathrm{L}$. In contrast, Lee et al. (2008) used a plastic culture plate as a test chamber and estimated the $96 \mathrm{~h}-\mathrm{LC} 50$ of TBT for adult copepods to be $50 \mu \mathrm{g} / \mathrm{L}$. The differences of test chamber material may have contributed to a difference of TBT concentrations in the test chambers.

In recent studies, TBT has been detected at a maximum concentration of $2.2 \mathrm{ng} / \mathrm{L}(0.9 \mathrm{ng} \mathrm{Sn} / \mathrm{L})$ in seawater sampled from the port of Zanzibar City in Tanzania (Sheikh et al., 2020), and diazinon has been detected at a maximum concentration of $0.71 \mathrm{ng} / \mathrm{L}$ in seawater sampled from Spanish coastal waters (Köck-Schulmeyer et al., 2019). These concentrations are lower than the PNEC of TBT (8.8 ng/L (3.6 ng $\mathrm{Sn} / \mathrm{L})$ ) and diazinon $(77.3 \mathrm{ng} / \mathrm{L})$, respectively, in this study. The corresponding hazard ratios are $0.25(0.9 / 3.6)$ for TBT and 0.009 $(0.71 / 77.3)$ for diazinon. These results suggest low or negligible risk of TBT and diazinon in the coastal zone. In the intertidal zone, however, TBT as well as radionuclides and PAHs have been detected in wharf roaches (Honda et al., 2018; Qiu et al., 2017; Undap et al., 2013a). Thus, intertidal organisms may be exposed to a mixture of pollutants. The additive behavior of the toxicity of pollutants has been well documented, and Qiu et al. (2019) have shown that a mixture of TBT and polychlorinated biphenyls (PCBs) can be toxic to medaka embryos even if there is no toxicity to medaka embryos associated with exposure to the same concentrations of TBT or PCBs individually. We therefore suggest that further research will be required to evaluate the toxicity of combinations of chemical pollutants to intertidal organisms such as T. japonicus.

In conclusion, we performed acute and life-cycle toxicity tests using T. japonicus and evaluated the effects of TBT and diazinon on the offspring of $T$. japonicus adults. Our results suggested that the risk of exposure to TBT or diazinon individually was negligible in the intertidal zone. However, several pollutants might be simultaneously present and contaminate intertidal organisms. The combined toxicity of several pollutants may adversely affect the intertidal zone ecosystem. Further research is therefore needed to evaluate the toxic effects of combinations of several pollutants on intertidal zone organisms such as T. japonicus.

\section{AUTHOR CONTRIBUTIONS}

Y. Takai designed the study, analyzed the data, and wrote the paper. W. Tanoue performed the acute and life-cycle toxicity tests and measured the TBT and diazinon concentrations in the test solutions. X. Qiu supervised the statistical analysis in the study. $\mathrm{H}$ Takaku provided the T. japonicus that was used in this study. I. J. Kang supervised the work and assisted with writing the paper. Y. Shimasaki designed the study and supervised the work. T. Honjo and Y. Oshima designed the study, supervised the work, and provided facilities and resources. All authors assisted in editing the manuscript and approved the final version.

\section{REFERENCES}

Bailey, H. C., Deanovic, L., Reyes, E., Kimball, T., Larson, K., Cortright, K., Connor, V., Hinton, D.E., 2000. Diazinon and chlorpyrifos in urban waterways in northern California, USA. Environ. Toxicol. Chem. 19, 82-87

Barka, S., Pavillon, J. F., Amiard, J. C., 2001. Influence of different essential and non-essential metals on MTLP levels in the copepod Tigriopus brevicornis. Comp. Biochem. Physiol. C Toxicol. Pharmacol. 128, 479-493

Batley, G. E., Scammell, M. S., 1991. Research on tributyltin in Australian estuaries. Appl. Organomet. Chem. 5, 99-105

Beiras, R., 2018. Marine pollution, Elsevier

Cardwell, R., Brancato, M. S., Toll, J., DeForest, D., Tear, L., 1999 Aquatic ecological risks posed by tributyltin in US surface waters: Pre-1989-1997 data. Environ. Toxicol. Chem. 18, 567-577

Carter, R. J., Turoczy, N. J., Bond, A. M., 1989. Container adsorption of tributyltin (TBT) compounds: implications for environmental analysis. Environ. Sci. Technol. 23, 615-617

Chen, J., Zhang, W., Wan, Z., Li, S., Huang, T., Fei, Y., 2019. Oil spills from global tankers: Status review and future governance. J. Clean. Prod. 227, 20-32

Davies, D. B., Holub, B. J., 1980. Toxicological evaluation of dietary diazinon in the rat. Arch. Environ. Contam. Toxicol. 9 $637-650$

Derbalah, A., Chidya, R., Jadoon, W., Sakugawa, H., 2019 Temporal trends in organophosphorus pesticides use and concentrations in river water in Japan, and risk assessment. $J$. Environ. Sci. 79, 135-152

ECC, 2003. Technical guidance document on risk assessment, part II, ECC (European Community Commission)

Fu, J., Mai, B., Sheng, G., Zhang, G., Wang, X., Peng, P., Xiao, X., Ran, R., Cheng, F., Peng, X., Wang, Z., Tang, U.W., 2003. Persistent organic pollutants in environment of the Pearl River Delta, China: An overview. Chemosphere 52, 1411-1422

Gadd, G. M., 2000. Microbial interactions with tributyltin compounds: detoxification, accumulation, and environmental fate. Sci. Total Environ. 258, 119-127

Gibson, R. N., 2001. Intertidal fishes. Encycl. Ocean Sci. Second Ed. 280-285

Góngora-Echeverría, V. R., Martin-Laurent, F., Quintal-Franco, C., Lorenzo-Flores, A., Giácoman-Vallejos, G., Ponce-Caballero, C., 
2019. Dissipation and adsorption of 2,4-D, atrazine, diazinon, and glyphosate in an agricultural soil from Yucatan State, Mexico. Water. Air. Soil Pollut. 230, 131

Griffero, L., Alcántara-Durán, J., Alonso, C., Rodríguez-Gallego, L., Moreno-González, D., García-Reyes, J.F., Molina-Díaz, A., Pérez-Parada, A., 2019. Basin-scale monitoring and risk assessment of emerging contaminants in South American Atlantic coastal lagoons. Sci. Total Environ. 697, 134058

Guo, F., Wang, L., Wang, W. X., 2012. Acute and chronic toxicity of polychlorinated biphenyl 126 to Tigriopus japonicus: Effects on survival, growth, reproduction, and intrinsic rate of population growth. Environ. Toxicol. Chem. 31, 639-645

Honda, M., Qiu, X., Koyama, J., Uno, S., Undap, S.L., Shimasaki, Y., Oshima, Y., 2018. The wharf roach, Ligia sp., a novel indicator of polycyclic aromatic hydrocarbon contamination in coastal areas. Int. J. Environ. Res. 12, 1-11

Horiguchi, T., Shiraishi, H., Shimizu, M., Morita, M., 1997. Imposex in sea snails, caused by organotin (tributyltin and triphenyltin) pollution in Japan: a survey. Appl. Organomet. Chem. 11, 451-455

Hutchinson, T. H., Pounds, N. A., Hampel, M., Williams, T.D., 1999. Life-cycle studies with marine copepods (Tisbe battagliai) exposed to 20-hydroxyecdysone and diethylstilbestrol. Environ. Toxicol. Chem. 18, 2914-2920

IMO, 2020. Status of Conventions. Int. Marit. Organ

Inoue, S., Oshima, Y., Usuki, H., Hamaguchi, M., Hanamura, Y., Kai, N., Shimasaki, Y., Honjo, T., 2006. Effects of tributyltin maternal and/or waterborne exposure on the embryonic development of the Manila clam, Ruditapes philippinarum. Chemosphere $\mathbf{6 3}$, 881-888

Itoh, K., Imai, I., 1987. Rafido-So. In: The Japan Fisheries Resources Conservation Association (Ed.), A guide for studies of red tide organisms. Shuwa, Tokyo

Keizer, J., D’Agostino, G., Nagel, R., Volpe, T., Gnemi, P., Vittozzi, L., 1995. Enzymological differences of AChE and diazinon hepatic metabolism: correlation of in vitro data with the selective toxicity of diazinon to fish species. Sci. Total Environ. 171, 213-220

Ko, M. M. C., Bradley, G. C., Neller, A. H., Broom, M. J., 1995. Tributyltin contamination of marine sediments of Hong Kong. Mar. Pollut. Bull. 31, 249-253

Kobayashi, K., Rompas, R. M., Maekawa, T., Imada, N., Oshima, Y., 1990. Changes in metabolic activity of tiger shrimp larvae at different stages to fenitrothion, an organophosphorus insecticide. Nippon Suisan Gakkaishi 56, 489-496

Köck-Schulmeyer, M., Postigo, C., Farré, M., Barceló, D., López de Alda, M., 2019. Medium to highly polar pesticides in seawater: Analysis and fate in coastal areas of Catalonia (NE Spain). Chemosphere 215, 515-523

Kwok, K. W. H., Leung, K. M. Y., 2005. Toxicity of antifouling biocides to the intertidal harpacticoid copepod Tigriopus japonicus (Crustacea, Copepoda): Effects of temperature and salinity. Mar. Pollut. Bull. 51, 830-837

Lee, K. W., Raisuddin, S., Hwang, D. S., Park, H. G., Dahms, H. U., Ahn, I.Y., Lee, J.S., 2008. Two-generation toxicity study on the copepod model species Tigriopus japonicus. Chemosphere 72, 1359-1365

Lee, K. W., Shim, W. J., Yim, U. H., Kang, J. H., 2013. Acute and chronic toxicity study of the water accommodated fraction (WAF), chemically enhanced WAF (CEWAF) of crude oil and dispersant in the rock pool copepod Tigriopus japonicus. Chemosphere 92, 1161-1168

Marcial, H. S., Hagiwara, A., Snell, T. W., 2003. Estrogenic compounds affect development of harpacticoid copepod Tigriopus japonicus. Environ. Toxicol. Chem. 22, 3025-3030.

Matthiessen, P., Gibbs, P. E., 1998. Critical appraisal of the evidence for tributyltin-mediated endocrine disruption in mollusks. Environ. Toxicol. Chem. 17, 37-43

Murai, R., Takahashi, S., Tanabe, S., Takeuchi, I., 2005. Status of butyltin pollution along the coasts of western Japan in 2001, 11 years after partial restrictions on the usage of tributyltin.
Mar. Pollut. Bull. 51, 940-949

Nakagawa, Y., Moore, G., 1999. Role of mitochondrial membrane permeability transition in p-hydroxybenzoate ester-induced cytotoxicity in rat hepatocytes. Biochem. Pharmacol. 58, 811816

Ngolo, P., Nawiri, M., Machocho, A., Oyieke, H., 2019. Pesticide residue levels in soil, water, kales and tomatoes in Ewaso Narok Wetland, Laikipia, County, Kenya. J. Sci. Res. Reports 24, 1-11

O’Brien, P., Feldman, H., Grill, E., Lewis, A., 1988. Copper tolerance of the life history stages of the splashpool copepod Tigriopus californicus (Copepoda, Harpacticoida). Mar. Ecol. Prog. Ser. 44, 59-64

Piegorsch, W. W., Bailer, A. J., 2005. Analyzing Environmental Data, Chapter 4 Quantitative Risk Assessment with StimulusResponse Data. Wiley

Qiu, X., Kim, S., Kang, I. J., Hano, T., Shimasaki, Y., Oshima, Y., 2019. Combined toxicities of tributyltin and polychlorinated biphenyls on the development and hatching of Japanese medaka (Oryzias latipes) embryos via in ovo nanoinjection. Chemosphere 225, 927-934

Qiu, X., Undap, S. L., Honda, M., Sekiguchi, T., Suzuki, N., Shimasaki, Y., Ando, H., Sato-Okoshi, W., Wada, T., Sunobe, T., Takeda, S., Munehara, H., Yokoyama, H., Momoshima, N., Oshima, Y., 2017. Pollution of radiocesium and radiosilver in wharf roach (Ligia sp.) by the Fukushima Dai-ichi Nuclear Power Plant accident. J. Radioanal. Nucl. Chem. 311, 121126

Raisuddin, S., Kwok, K. W. H., Leung, K. M. Y., Schlenk, D., Lee, J. S., 2007. The copepod Tigriopus: A promising marine model organism for ecotoxicology and environmental genomics. Aquat. Toxicol. 83, 161-173

Rhee, J. S., Raisuddin, S., Lee, K. W., Seo, J. S., Ki, J. S., Kim, I. C., Park, H. G., Lee, J. S., 2009. Heat shock protein (Hsp) gene responses of the intertidal copepod Tigriopus japonicus to environmental toxicants. Comp. Biochem. Physiol. C Toxicol. Pharmacol. 149, 104-112

Rompas, R. M., Kobayashi, K., Oshima, Y., Imada, N., Yamato, K., Mitsuyasu, Y., 1989. Relationship between toxicity and acetylcholinesterase inhibition of some thiono-and oxo-form organophosphates in tiger shrimp larvae at different stages. Nippon Suisan Gakkaishi 55, 669-673

Sheikh, M. A., Fasih, M. M., Strand, J., Ali, H. R., Bakar, A. H., Sharif, H. M., 2020. Potential of silicone passive sampler for tributyltin (TBT) detection in tropical aquatic systems. Reg. Stud. Mar. Sci. 35, 101171

Shimasaki, Y., Kitano, T., Oshima, Y., Inoue, S., Imada, N., Honjo, T., 2003. Tributyltin causes masculinization in fish. Environ. Toxicol. Chem. 22, 141-144

Tipmanee, D., Deelaman, W., Pongpiachan, S., Schwarzer, K., Sompongchaiyakul, P., 2012. Using polycyclic aromatic hydrocarbons (PAHs) as a chemical proxy to indicate Tsunami 2004 backwash in Khao Lak coastal area, Thailand. Nat. Hazards Earth Syst. Sci. 12, 1441-1451

Undap, S. L., Matsunaga, S., Honda, M., Sekiguchi, T., Suzuki, N., Khalil, F., Qiu, X., Shimasaki, Y., Ando, H., Sato-Okoshi, W. Sunobe, T., Takeda, S., Munehara, H., Oshima, Y., 2013a. Accumulation of organotins in wharf roach (Ligia exotica Roux) and its ability to serve as a biomonitoring species for coastal pollution. Ecotoxicol. Environ. Saf. 96, 75-79

Undap, S. L., Nirmala, K., Miki, S., Inoue, S., Xuchun, Q., Honda, M., Shimasaki, Y., Oshima, Y., 2013b. High tributyltin contamination in sediments from ports in Indonesia and northern Kyushu, Japan. J. Fac. Agric. Kyushu Univ. 58, 131-135

Verriopoulos, G., Moraïtou-Apostolopoulou, M., 1982 Differentiation of the sensitivity to copper and cadmium in different life stages of a copepod. Mar. Pollut. Bull. 13, 123-125

Zhou, F., Guo, H., Hao, Z., 2007. Spatial distribution of heavy metals in Hong Kong's marine sediments and their human impacts: A GIS-based chemometric approach. Mar. Pollut. Bull. 54, 1372-1384 